\title{
Pharmacological characterization of cnidarian extracts from the Caribbean Sea: evaluation of anti-snake venom and antitumor properties
}

Cláudia S. Oliveira ${ }^{1,2,3}$, Cleópatra A. S. Caldeira ${ }^{1,2,3}$, Rafaela Diniz-Sousa ${ }^{1,2,3}$, Dolores L. Romero ${ }^{4}$, Silvana Marcussi ${ }^{5}$, Laura A. Moura ${ }^{6}$, André L. Fuly ${ }^{6}$, Cicília de Carvalho ${ }^{7}$, Walter L. G. Cavalcante ${ }^{7,8}$, Márcia Gallacci ${ }^{7}$, Maeli Dal Pai ${ }^{9}$, Juliana P. Zuliani ${ }^{1,2,3}$, Leonardo A. Calderon ${ }^{1,2,3}$ and Andreimar M. Soares ${ }^{1,2,3,10^{*}}$

\begin{abstract}
Background: Cnidarians produce toxins, which are composed of different polypeptides that induce pharmacological effects of biotechnological interest, such as antitumor, antiophidic and anti-clotting activities. This study aimed to evaluate toxicological activities and potential as antitumor and antiophidic agents contained in total extracts from five cnidarians: Millepora alcicornis, Stichodactyla helianthus, Plexaura homomalla, Bartholomea annulata and Condylactis gigantea (total and body wall).

Methods: The cnidarian extracts were evaluated by electrophoresis and for their phospholipase, proteolytic, hemorrhagic, coagulant, fibrinogenolytic, neuromuscular blocking, muscle-damaging, edema-inducing and cytotoxic activities.

Results: All cnidarian extracts showed indirect hemolytic activity, but only $S$. helianthus induced direct hemolysis and neurotoxic effect. However, the hydrolysis of NBD-PC, a PLA 2 substrate, was presented only by the C. gigantea (body wall) and S. helianthus. The extracts from P. homomalla and S. helianthus induced edema, while only C. gigantea and S. helianthus showed intensified myotoxic activity. The proteolytic activity upon casein and fibrinogen was presented mainly by $B$. annulata extract and all were unable to induce hemorrhage or fibrinogen coagulation. Cnidarian extracts were able to neutralize clotting induced by Bothrops jararacussu snake venom, except M. alcicornis. All cnidarian extracts were able to inhibit hemorrhagic activity induced by Bothrops moojeni venom. Only the C. gigantea (body wall) inhibited thrombin-induced coagulation. All cnidarian extracts showed antitumor effect against Jurkat cells, of which C. gigantea (body wall) and S. helianthus were the most active; however, only C. gigantea (body wall) and M. alcicornis were active against B16F10 cells.
\end{abstract}

Conclusion: The cnidarian extracts analyzed showed relevant in vitro inhibitory potential over the activities induced by Bothrops venoms; these results may contribute to elucidate the possible mechanisms of interaction between cnidarian extracts and snake venoms.

Keywords: Caribbean sea cnidarians, Bioprospection, Antiophidic, Antitumor, Natural products

\footnotetext{
*Correspondence: andreimarsoares@gmail.com; andreimar.soares@fiocruz.br

${ }^{1}$ Centro de Estudos de Biomoléculas Aplicadas a Saúde (CEBio), Fundação

Oswaldo Cruz de Rondônia (Fiocruz Rondônia), Porto Velho, RO, Brazil

${ }^{2}$ Brazilian Marine Biotechnology Network (BioTecMar Network), Porto Velho,

Brazil

Full list of author information is available at the end of the article
}

(c) The Author(s). 2018 Open Access This article is distributed under the terms of the Creative Commons Attribution 4.0 International License (http://creativecommons.org/licenses/by/4.0/), which permits unrestricted use, distribution, and reproduction in any medium, provided you give appropriate credit to the original author(s) and the source, provide a link to the Creative Commons license, and indicate if changes were made. The Creative Commons Public Domain Dedication waiver (http://creativecommons.org/publicdomain/zero/1.0/) applies to the data made available in this article, unless otherwise stated. 


\section{Background}

Marine organisms, which comprise half of the total global biodiversity, have been recognized as the largest remaining reservoir of novel compounds to be evaluated for drug activity [1-6]. Animals belonging the phylum Cnidaria are of great importance for studies of pharmacological and toxicological assessments. The composition of cnidarian venoms remains incompletely elucidated. However, several of their compounds have been described, including peptides, proteins, purines, quaternary ammonium compounds, biogenic amines and betaines [1, 7-11].

Venoms from such animals as snakes [12-14], scorpions $[15-18]$, anurans $[19,20]$, cone snails $[21,22]$ and cnidarians [23-25] have been used as a source of bioactive compounds for the prospection of lead compounds potentially useful for the development of new anticancer therapies $[26,27]$. This fact has provoked a growing worldwide interest in the screening of proteins, peptides, marine natural products (MNPs) from cnidarians in order to discover new anticancer bioactive compounds [28, 29].

The use of genomic and proteomic approaches had permitted a rapid increase in the number of sequences from cnidarians deposited in protein and gene databases [30-32]. Some of these toxins have been used for the development of anticancer molecules. One interesting example is the hemolytic toxin (HT) from Stichodactyla helianthus sea anemone which was conjugated with an antibody towards an antigen expressed on immature $\mathrm{T}$ lymphocytes (IOR-T6) producing an o-hemolytic hybrid IOR-T6-HT that showed toxicity against CEM cells expressing the IOR-T6 antigen and non-toxic effects for K562 cells without the antigen [33].

Additionally, several marine natural products are able to inhibit the toxic effects of snake venoms, such as extracts from Plocamium braziliense [34], Canistrocarpus cervicornis [35] and seaweed Prasiola crispa [36]. The marine extracts that also inhibit $\mathrm{PLA}_{2}$ activity include manoalide [37], vidalols, and a group of terpenoids that contain masked 1,4-dicarbonyl moieties. Furthermore, the biotechnological potential of $\mathrm{PLA}_{2}$ inhibitors may provide therapeutic molecular models that exert antiophidian activity to supplement the conventional serum therapy against these multifunctional enzymes [38, 39].

This study aimed to evaluate toxicological activities and their efficacy against tumor and snake-venom toxic activities from five Caribbean Sea cnidarian species of the hydrozoa class: Millepora alcicornis, Plexaura homomalla and Cnidarians of the anthozoa class: Condylactis gigantea (total and body wall), Stichodactyla helianthus, and Bartholomea annulata.

\section{Methods}

\section{Materials and reagents}

The synthetic fluorescent substrates Acyl 6:0 NBD phospholipids, NBD-phosphatidylcholine (PC) and NBD- phosphatidic acid (PA) were purchased from Avanti Polar Lipids Inc. (USA). The reagents used in the electrophoresis, salts and other reagents were obtained from Sigma Chemical Company (USA).

\section{Cnidarian extracts}

The cnidarians specimens were collected in the coast of Havana City during a one-year period. The extracts of corals were obtained as previously described by [40], whereas anemone extracts were obtained according to [41]. Protein quantitation was based on the Bradford method (BioRad) using bovine serum albumin (BSA) as a standard.

\section{Animals}

Adult male mice weighing 25 to $30 \mathrm{~g}$ were maintained under a $12 \mathrm{~h}$ light-dark cycle (lights on at 07:00 h) in a temperature-controlled environment $\left(22 \pm 2{ }^{\circ} \mathrm{C}\right)$ for at least ten days prior to the experiments. Food and water were freely available. Animal procedures were in accordance with the guidelines prepared by the Committee on Care and Use of Laboratory Animal Resources, National Research Council, USA. The ethical aspects related to the project were approved by the Ethics Committee on Animal Use (No. 2012/1) and the Ethics Committee (102/2009) for Research on Human Beings from Brazil (CAAE: 14204413.5.0000.0011).

\section{Electrophoresis}

SDS-PAGE $12.5 \%(\mathrm{~m} / \mathrm{v})$ was carried out as previously described [42]. $500 \mu \mathrm{g}$ samples C. gigantea (body-wall), $C$. gigantea (total), M. alcicornes, S. helianthus, $P$. homomalla and B. annulata were pretreated in reducing conditions (SDS plus $\beta$-mercaptoethanol) at $100{ }^{\circ} \mathrm{C}$ for 5 min. Gels were stained with $0.1 \%$ Coomassie brilliant blue R-350 in ethanol: acetic acid $(5: 1, v / v)$ for $15 \mathrm{~min}$ and discolored in $10 \%$ acetic acid. The molecular mass was estimated by interpolation from a linear logarithmic plot of relative molecular mass versus distance of migration using standard molar mass markers (SDS7 Sigma-Aldrich).

\section{Phospholipase activity}

The Phospholipase $\mathrm{A}_{2}\left(\mathrm{PLA}_{2}\right)$ activity was measured using the indirect hemolytic assay on agarose gels containing red blood cells and egg yolk phospholipids [43]. The hemolytic activity was evaluated spectrophotometrically using suspensions of fresh human RBC (red blood cells) as previously described $[44,45]$.

$\mathrm{PLA}_{2}$ activity was evaluated also through the hydrolysis of synthetic fluorescent phospholipid, using the fluorescent substrate Acyl 6:0 NBD phospholipid, NBDphosphatidylcholine (NBD-PC). The assay was perfor med using a spectrofluorimeter (Shimadzu, RF-5301PC, 
software RFPC) with excitation and emission wavelengths of 460 and $534 \mathrm{~nm}$, respectively. The enzymatic activity of each cnidarian extract was evaluated for $250 \mathrm{~s}$ after the addition of substrate $(3.3 \mu \mathrm{g} / \mathrm{mL}$, final concentration) in a reaction medium containing $50 \mathrm{mM}$ Tris- $\mathrm{HCl}$, and $8 \mathrm{mM}$ $\mathrm{CaCl}_{2}, \mathrm{pH} 7.5$, at room temperature.

\section{Proteolytic activity assay}

Proteolytic activity upon fibrinogen was measured as described by [46] with some modifications. Fibrinogen $(70 \mu \mathrm{g})$ diluted in PBS was incubated with different amounts of cnidarian extracts diluted in $20 \mu \mathrm{L}$ buffer (pH 7.5) at $37^{\circ} \mathrm{C}$ for $2 \mathrm{~h}$. The reaction was stopped with $20 \mu \mathrm{L}$ of a solution containing $10 \%(\mathrm{v} / \mathrm{v})$ glycerol, $10 \%$ $(\mathrm{v} / \mathrm{v}) \beta$-mercaptoethanol, 2\% (v/v) SDS, and 0.05\% (w/v) bromophenol blue. Fibrinogen hydrolysis was demonstrated by SDS-PAGE using $12 \%$ polyacrylamide gels. Proteolytic activity upon casein was measured as described by [47]. Cnidarian extracts $(100$ and $500 \mu \mathrm{g})$ were incubated for $30 \mathrm{~min}$ at $37{ }^{\circ} \mathrm{C}$ in a solution of $0.1 \mathrm{M}$ Tris- $\mathrm{HCl} \mathrm{pH} 9.0$ containing $1 \%$ casein. After the incubation period, $1.5 \mathrm{~mL}$ of $30 \%$ TCA was added to each sample to stop the enzymatic reaction and centrifuged at $340 \times \mathrm{g}$ for $25 \mathrm{~min}$. Then, the samples were read on a spectrophotometer at a wavelength of $280 \mathrm{~nm}$. One unit of protease activity was defined as the amount of enzyme that produces an increase in absorbance of 0.001 units $/$ minute at $280 \mathrm{~nm}$.

\section{Hemorrhagic activity assay}

Hemorrhagic activity was quantitatively estimated by the method of [48] with some modifications. Groups of six Swiss mice (18-22 g) were shaved on the back and then intradermally (i.d.) injected with different doses of cnidarians extracts or snake venoms, in $50 \mu \mathrm{L}$ of phosphate buffered saline (PBS). After $2 \mathrm{~h}$, animals were anesthetized and euthanized. The shaved back skin was removed and the hemorrhagic halo diameter was measured. The minimum hemorrhagic dose (MHD) was obtained from the mean of these diameters $(\mathrm{mm})$. The MHD is defined as the dose of snake venom or extract that produces a hemorrhagic lesion of $10 \mathrm{~mm}$ diameter after $2 \mathrm{~h}$.

\section{Coagulant activity assay}

The clotting time was determined by mixing $20 \mu \mathrm{L}$ of the samples (in $0.15 \mathrm{M} \mathrm{NaCl}, \mathrm{pH} 7.4$ ) with $200 \mu \mathrm{L}$ of citrated bovine plasma at $37^{\circ} \mathrm{C}$. The $B$. jararacussu snake venom $(20 \mu \mathrm{g})$ was assayed in order to determine the minimum coagulant dose (corresponding to the time between 1 and $1.2 \mathrm{~s}-100 \%$ activity). For the neutralization trials, the snake venom was previously incubated with different cnidarian extracts for $30 \mathrm{~min}$ at $37^{\circ} \mathrm{C}$, at different proportions $(1: 5,1: 10$ and 1:30, w/w).

\section{Neuromuscular blocking}

Mice were euthanized by exsanguination after previous cervical dislocation. Phrenic-diaphragm (PD) preparation was removed and mounted vertically in a conventional isolated organ-bath chamber containing $15 \mathrm{~mL}$ of physiological solution of the following composition $(\mathrm{mmol} / \mathrm{L})$ : $\mathrm{NaCl}, 135 ; \mathrm{KCl}, 5 ; \mathrm{MgCl}_{2}, 1 ; \mathrm{CaCl}_{2}, 2 ; \mathrm{NaHCO}_{3}, 15$; $\mathrm{Na}_{2} \mathrm{HPO}_{4}, 1$; glucose, 11 . This solution was bubbled with carbogen $\left(95 \% \mathrm{O}_{2}\right.$ and $\left.5 \% \mathrm{CO}_{2}\right)$. The preparation was attached to an isometric force transducer (Grass, FT03) for recording the twitch tension. The transducer signal output was amplified and recorded on a computer via a transducer signal conditioner (Gould, 13-6615-50) with an Acquire Lab Data Acquisition System (Gould). The resting tension was $5 \mathrm{~g}$; indirect contractions were stimulated by supramaximal pulses $(0.2 \mathrm{~Hz}, 0.5 \mathrm{~ms})$ delivered from an electronic stimulator (Grass-S88 K) and applied to the phrenic nerve by means of a suction electrode. The preparation was allowed to stabilize for $45 \mathrm{~min}$ before the addition of a single concentration of toxin [49].

\section{Muscle-damaging activity Morphological analysis}

At the end of the myographic study, the diaphragm muscle was removed from the bath and frozen in liquid nitrogen. Transverse sections ( $8 \mathrm{~mm}$ thick) were cut out at $-20{ }^{\circ} \mathrm{C}$ in a cryostat and stained with hematoxylin and eosin (HE) prior to examination by light microscopy [50]. Muscle damage was quantified in HE stained preparations, using an Analysis Imaging System (Leica, Qwin). The number of fibers with lesions was expressed as a percentage of the total number of cells (muscle damage index), in three non-overlapping non-adjacent areas of each muscle, observed at the same magnification.

\section{Creatine kinase release}

The creatine kinase (CK) assay was carried out using the CK-UV kinetic kit from Sigma Chem. Co. Different cnidarian extracts were injected (i.m., $50 \mu \mathrm{L}$ ) into Swiss male mice weighing 18-22 g $(n=6)$. The control animals received $0.15 \mathrm{M}$ PBS. After $3 \mathrm{~h}$, the blood from the tail was collected in heparin-coated tubes and centrifuged for plasma separation. The amount of CK was then determined using $4 \mu \mathrm{L}$ of plasma, which was incubated for $3 \mathrm{~min}$ at $37^{\circ} \mathrm{C}$ with $1.0 \mathrm{~mL}$ of the reagent. Enzyme activity was expressed in international units per liter (IU/L), with one unit of activity corresponding to phosphorylation of $1 \mu \mathrm{mol}$ of creatine/min at $25^{\circ} \mathrm{C}$.

\section{Edema inducing activity}

Groups of six Swiss male mice (18-22 g) were injected in the sub plantar region with different doses of cnidarian extracts in $50 \mu \mathrm{L}$ of PBS. After $0.5,1$ and $3 \mathrm{~h}$, the paw edema was measured using a low-pressure spring 
caliper (Mytutoyo-japan) [51, 52]. The zero time values were then subtracted and the differences reported as median $\% \pm$ S.D.

\section{Cytotoxic activity}

Tumor cell cytotoxic activity of cnidarian extracts on human acute T-cell leukemia (Jurkat) and B16F10 cell lines were assayed using the MTT method according to [53]. Cells were dispersed in 96-well plates at a density of $1 \times 10^{5}$ cells per well. After $24 \mathrm{~h}$ of culture, the media were removed and fresh media, with or without different concentrations of samples, were added into the wells and incubated for $24 \mathrm{~h}$. The extracts were evaluated at 1000, 100 and $10 \mu \mathrm{g} / \mathrm{mL}$ concentrations using Vincristine as positive control $(100 \mu \mathrm{g} / \mathrm{mL})$. Results were expressed as a percentage (\%).

\section{Statistical analysis}

Results were expressed as mean \pm S.D. Data was analyzed by ANOVA complemented by the Tukey-Kramer test, using the statistical program GraphPad 5.0. Values of $p<0.05$ were considered significant.

\section{Results and discussion}

The SDS-PAGE analysis in denaturing conditions of the cnidarian extracts showed the difference between extracts of C. gigantea (body-wall), C. gigantea (total), S. helianthus, $B$. annulata, $M$. alcicornes and P. homomalla. Considering that the extracts were obtained from the entire organism, it should be noted that the anatomy of $M$. alcicornes and $P$. homomalla is different from that of anemones. For this reason, the method of protein extraction must be differentiated for these organisms. Thus, it is possible that in the $500 \mu \mathrm{g}$ extract applied to the electrophoresis, a low protein yield made it impossible to visualize bands on the polyacrylamide gel (Fig. 1a).

The extracts of S. helianthus and C. gigantea (bodywall) hydrolyzed the NBD-PC substrate that is specific for the PLA $\mathrm{P}_{2}$ enzymes, which was not observed for the other extracts tested (Fig. 2b). Martins and coworkers [54] isolated a PLA 2 (CgPLA2) composed of $14 \mathrm{kDa}$ dimers and $29 \mathrm{kDa}$ monomer from the C. gigantea extract. Another study reported showed that Sticholysin I and II, two $19 \mathrm{kDa}$ pore-forming cytokines, present in the $S$. helianthus extract, low activity against specific substrates for phospholipase activity when tested alone [55].

However, fractions enriched with these two molecules together demonstrated a significant increase in phospholipase activity [56]. Although CgPLA $\mathrm{A}_{2}$ and Sticholysin I and II are known to exert phospholipase activity, it should be emphasized that the experiments were carried out with total extract. It is possible that these molecules are responsible for the hydrolysis promoted against the NBD-PC substrate, but we do not rule out the existence of other molecules that are components of the extract, which alone or in clusters may be acting in the hydrolysis of the NBD-PC substrate.

As shown in Fig. 2a, all extracts displayed indirect hemolytic activity. However, only extracts of $S$. helianthus and C. gigantea showed direct hemolytic activity by lysis of red blood cells, in a concentration-dependent

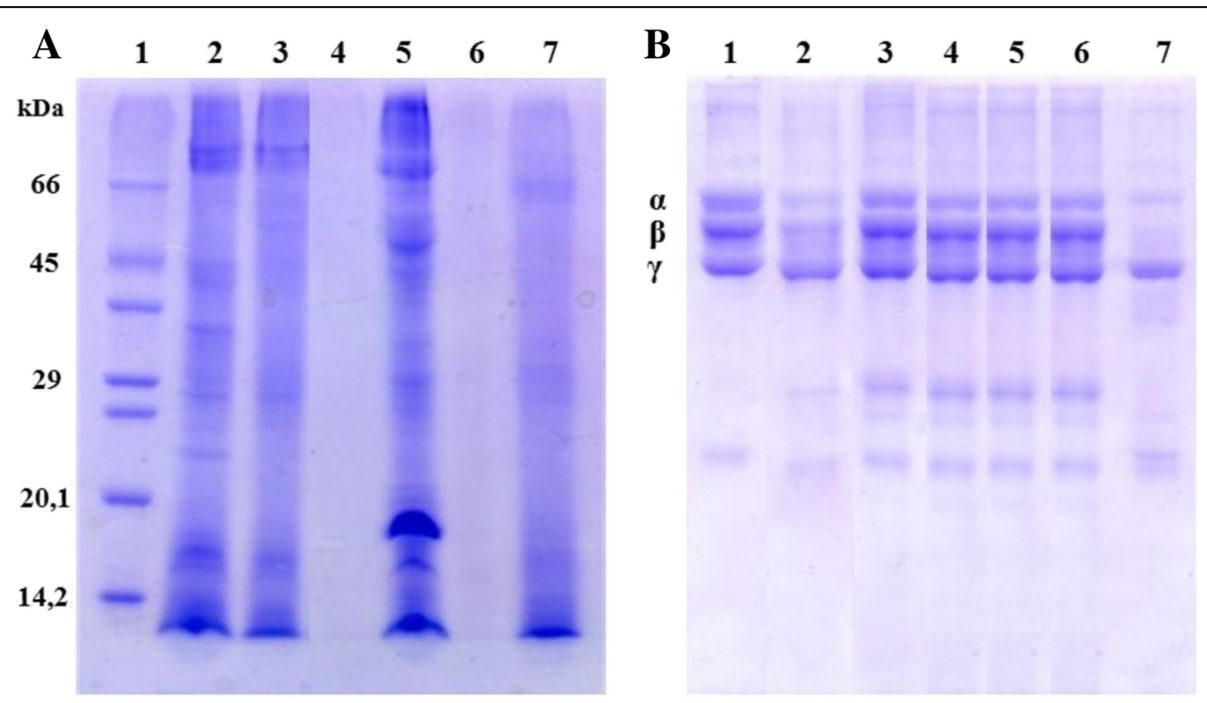

Fig. 1 (a) PAGE in the presence of SDS and $\beta$-mercaptoethanol. Lanes: 1 - standard, molecular-weight markers; 2 - C. gigantea (body-wall); 3 - C. gigantea (total); 4 - M. alcicornes; 5 - S. helianthus; 6 - P. homomalla; 7 - B. annulata; samples were applied containing $500 \mu \mathrm{g}$ of each extract. (b) Fibrinogenolytic activity of cnidarian extracts. 1 - Fibrinogen; 2 - fibrinogen + C. gigantean (body-wall); 3 - fibrinogen + C. gigantea (total); 4 fibrinogen $+M$. alcicornes; 5 - fibrinogen $+S$. helianthus; 6 - fibrinogen + P. homomalla; 7 - fibrinogen $+B$. annulata. Fibrinogen hydrolysis was demonstrated by SDS-PAGE using $12 \%$ polyacrylamide gels 

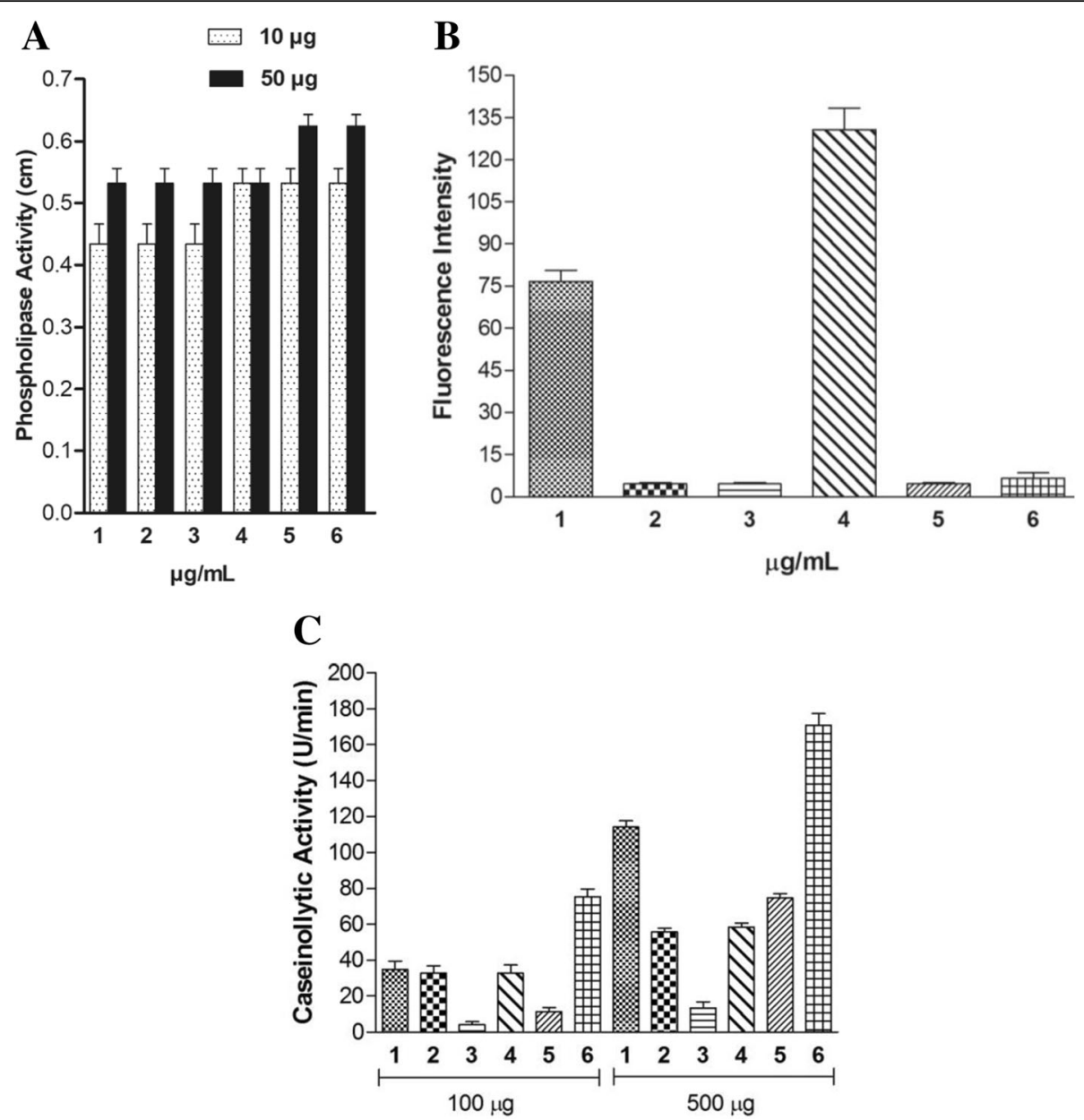

Fig. 2 Phospholipase and proteolytic activities induced by cnidarian extracts. (1) C. gigantea (body-wall), (2) C. gigantea (total), 3) M. alcicornis, (4) S. helianthus (5) P. homomalla and (6) B. annulata. (a) The PLA $\mathrm{A}_{2}$ activity using the indirect hemolytic assay on agarose gels containing red blood cells and egg-yolk phospholipids and by (b) Hydrolysis of the NBD-PC by cnidarian extracts (1-6). (c) Proteolytic activity upon $1 \%$ casein evaluated with 100 and $500 \mathrm{\mu g}$ of cnidarian extracts for $30 \mathrm{~min}$ at $37^{\circ} \mathrm{C}$. Results are reported as mean $\% \pm \mathrm{SD}(n=3)$

manner (Fig. 3a, b). Hemolysis was provoked not only by anemone extract as observed in $B$. annulate [57] and S. helianthus [58] but also by M. alcicornes aqueous extract [8]. In addition, Sticholysin II toxin isolated from $S$. helianthus has also been described for its hemolytic capacity $[45,59-63]$.

The extracts of C. gigantea (body wall) and B. annulata were able to partially hydrolyze the $\alpha$ and $\beta$ chains of fibrinogen; however, S. helianthus, M. alcicornis and $P$. homomalla were incapable of hydrolyze fibrinogen efficiently (Fig. 1b). The fibrinogenolytic assay was carried out using $50 \mu \mathrm{g}$ of the cnidarian extracts, whose proteolytic activity upon casein was evaluated; furthermore, the extract of $B$. annulata $(100 \mu \mathrm{g})$ hydrolyzed casein at $80 \mathrm{U} / \mathrm{min}$. The extracts of C. gigantea (body wall) and $B$. annulata at $500 \mu \mathrm{g}$ hydrolyzed casein at 118 and $170 \mathrm{U} /$ min, respectively (Fig. 2c).

As to the hemorrhagic effect, extracts of $M$. alcicornis and $P$. homomalla induced bleeding at a concentration of $150 \mu \mathrm{g}$ (Fig.4a) and inhibited bleeding induced by Bothrops snake venom. All cnidarians extracts tested inhibited the hemorrhagic activity induced by B. moojen $i$ venom at a ratio of $1: 30 \mathrm{w} / \mathrm{w}$, showing approximately $40 \%$ inhibition in the presence of extracts of C. gigantea (body wall), P. homomalla and M. alcicornis (Fig.4c). Interestingly, the B. neuwiedi venom extracts did not inhibit hemorrhage (Fig. 4b).

Coagulant activity was not induced by cnidarian extracts. However, all cnidarian extracts except $M$. alcicornis inhibited the coagulant activity induced by $B$. jararacussu venom at the ratios of 1:5 and 1:10 w/w. In this assay, the $B$. annulata extract at a $1: 30 \mathrm{w} / \mathrm{w}$ ratio showed the greatest ability to delay the clotting time of citrated plasma after the addition of $B$. jararacussu venom for more than $40 \mathrm{~min}$ (Table 1). The other extracts tested at the 1:30 w/w ratio presented lower inhibitory effect (Fig. 5). Additionally, C. gigantea body-wall extract at a concentration of $200 \mu \mathrm{g} / \mathrm{mL}$ were 

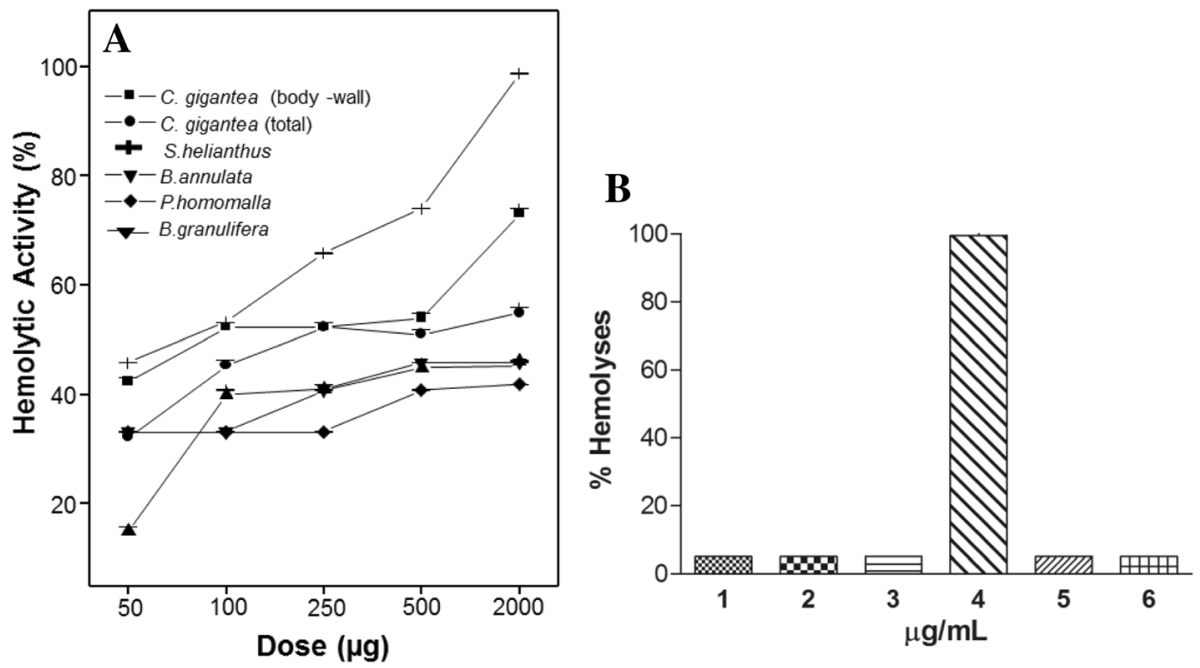

Fig. 3 Hemolytic activity of cnidarian extracts. (1) C. gigantea (body-wall), (2) C. gigantea (total), (3) M. alcicornis, (4) S. helianthus, (5) P. homomalla and (6) B. annulata. (a) Percentage of hemolytic activity tested at different doses from 50 to $2000 \mu \mathrm{g}$; (b) the hemolysis was tested at the same $200 \mu \mathrm{g} / \mathrm{mL}$ concentration

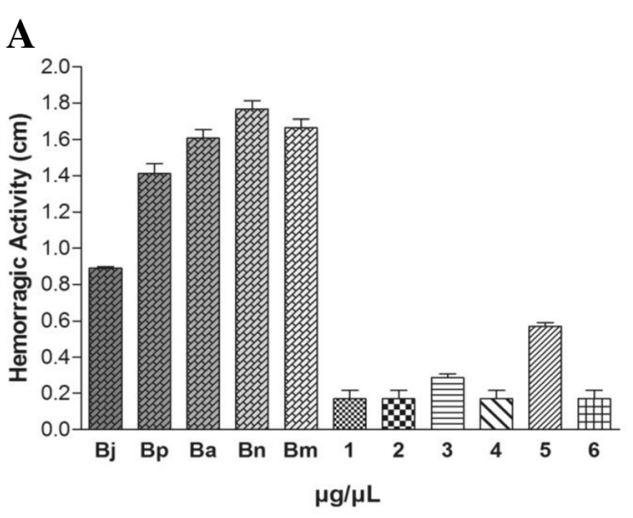

B

C
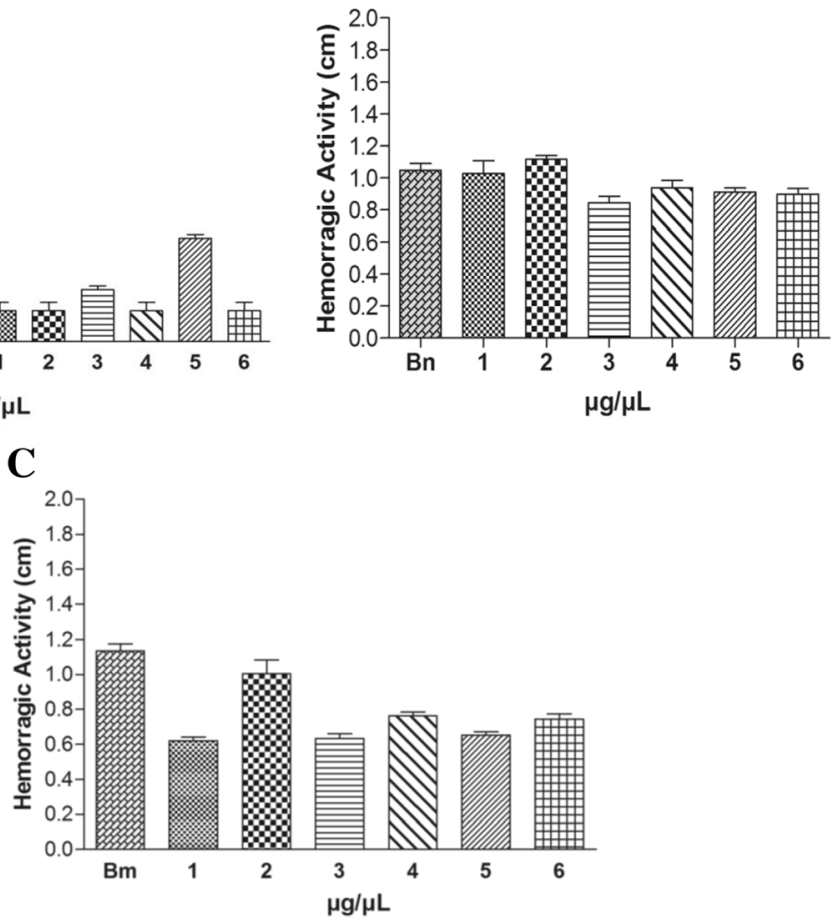

Fig. 4 Induction and Inhibition of hemorrhagic activity. (a) Hemorrhage induced by snake venoms: (Bj) B. jararacussu, (Bp) B. pirajai, (Ba) B. alternatus, (Bn) B. neuwiedi, (Bm) B. moojeni - all venoms at $30 \mu \mathrm{g}$ and, cnidarian extracts: (1) C. gigantea (body-wall), (2) C. gigantea (total), (3) M. alcicornis, (4) S. helianthus (5) P. homomalla, (6) B. annulata - all extracts at $150 \mu \mathrm{g}$. (b) Inhibition of hemorrhagic activity induced by B. neuwiedi $(\mathrm{Bn})$ at $20 \mu \mathrm{g}$ and; (c) Inhibition of haemorrhagic activity induced by B. moojeni $(\mathrm{Bm})$ at $10 \mu \mathrm{g}$. Results are reported as mean $\% \pm \mathrm{S}$. D $(\mathrm{n}=3)$ 
Table 1 Clotting activity inhibition from B. jararacussu snake venom by cnidarian extracts

\begin{tabular}{llll}
\hline & \multicolumn{3}{l}{ Clotting Time (min.) } \\
\cline { 2 - 4 } & Samples (1:5) & Samples (1:10) & Samples (1:30) \\
\hline B. jararacussu $(20 \mu \mathrm{g})$ & 1.08 & 1.10 & 1.05 \\
C. gigantea (body-wall) & 1.08 & 15 & 16.2 \\
C. gigantea (total) & $>3$ & $>3$ & 12.0 \\
M. alcicornis & $>3$ & 1.24 & 1.13 \\
S. helianthus & 2.4 & $>3$ & $>3$ \\
P. homomalla & $>3$ & $>3$ & 11.4 \\
B. annulata & 2.1 & $>3$ & $>40$ \\
\hline
\end{tabular}

able to inhibit thrombin-induced coagulation. This activity can be produced by the presence of protease inhibitors, as reported by [64], who showed the presence of protease inhibitory activity in the extract from the marine sponge Xetospongia muta (Poriphera) and in the sea anemones B. granulifera and B. annulata. According to these authors, this activity was dose-dependent and the molecule responsible for the inhibition had a low molecular weight. Di Bari and coworkers [65] also described the presence of protease inhibitors in aqueous extracts of marine sponges; all extracts were able to inhibit the activity and expression of matrix metalloproteinases (MMP-2 and MMP-9) in mice astrocyte culture.

At $3 \mathrm{~h}$ after the injection of $50 \mu \mathrm{g}$ of cnidarian extracts into the gastrocnemius mouse muscle, a slight myotoxic effect from the extracts of $M$. alcicornis and P. homomalla was observed, approximately $22 \%$ above those observed for the controls injected with PBS alone. The $C$.

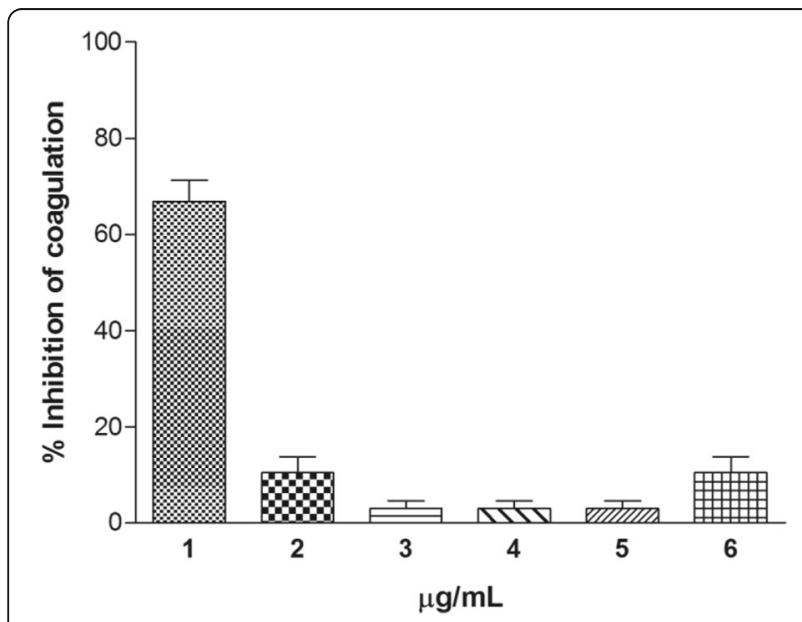

Fig. 5 Effect of cnidarian extracts on coagulation.(1) C. gigantea (body-wall), (2) C. gigantea (total), (3) M. alcicornis, (4) S. helianthus, (5) P. homomalla, (6) B. annulata, $200 \mu \mathrm{g} / \mathrm{mL}$ of the extract were pre-incubated with fibrinogen; clotting was then started by the addition of thrombin and monitored at $A_{405} \mathrm{~nm}$. Results are reported as mean $\% \pm S$. D $(n=3)$ gigantea (body-wall), C. gigantea (total) and S. helianthus presented increased activity, while extract of $B$. annulata did not show myotoxic effect.

Some studies have demonstrated the toxic effects of marine animals such as coral Millepora alcicornis, which causes systemic reactions in the kidney, lung and liver [8], and Millepora complanata, which presents non-peptide toxins highly lethal to mice with $\mathrm{LD}_{50}$ of $4.62 \mu \mathrm{g} / \mathrm{g}$ body weight [66]. The other cnidarian extracts tested, C. gigantea (body-wall), C. gigantea (total) and S. helianthus, showed a more pronounced myotoxic effect, smaller only compared with to those induced by $B$. jararacussu venom and the myotoxin BthTX-I, which are highly myotoxic (Fig. 6a). The edema induction was observed only in the presence of extracts from P. homomalla and S. helianthus (Fig. 6b).

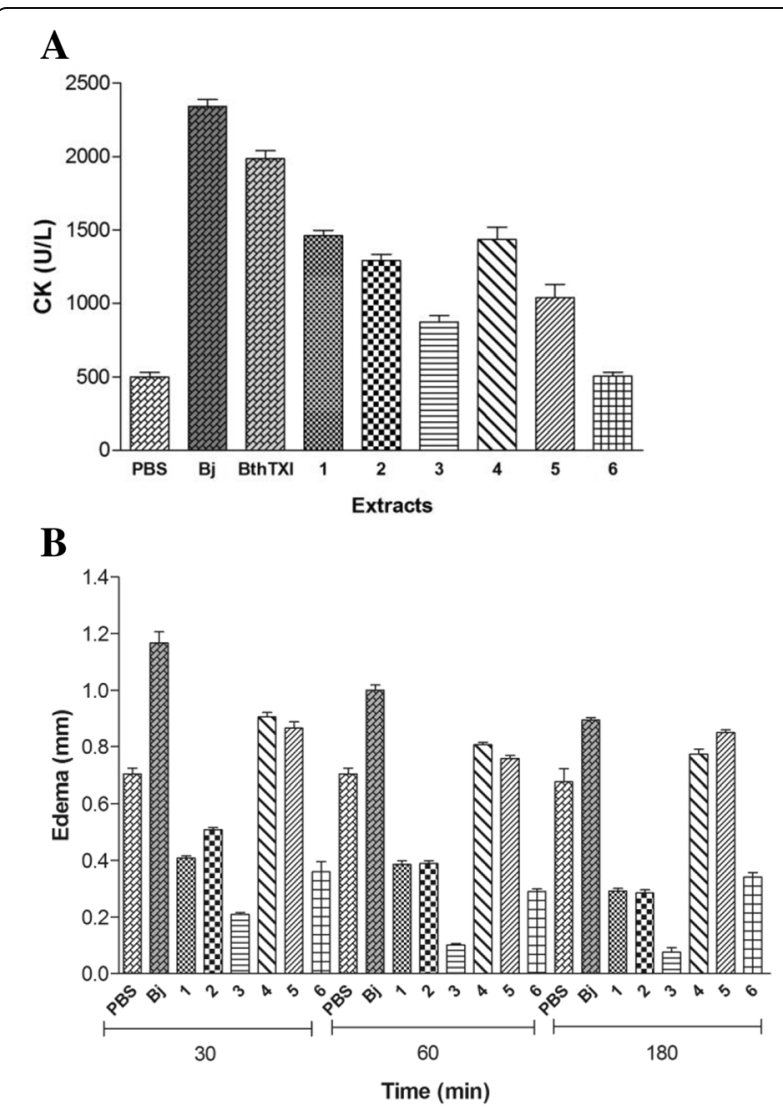

Fig. 6 Myotoxic activity and edema-induction by cnidarian extracts. (Bj) B. jararacussu snake venom and (BthTX-I) Bothropstoxin-I from B. jararacussu (1) C. gigantea (body-wall), (2) C. gigantea (total), (3) M. alcicornis, (4) S. helianthus (5) P. homomalla, (6) B. annulata. (a) CK activity was measured $3 \mathrm{~h}$ after the i.m injection of $50 \mu \mathrm{L}$ with $50 \mu \mathrm{g}$ of each cnidarian extracts (1-6) and $20 \mu \mathrm{g}$ of the Bj and BthTX-I. Results are presented as means \pm S.D. $(n=4)$. (b) Paw edema in Swiss mice was induced by injection of $100 \mu \mathrm{g}$ of cnidarian extracts and $10 \mu \mathrm{g}$ of Bj at 30,60 and 180 min. Results are reported as mean $\% \pm$ S. D $(n=6)$ 


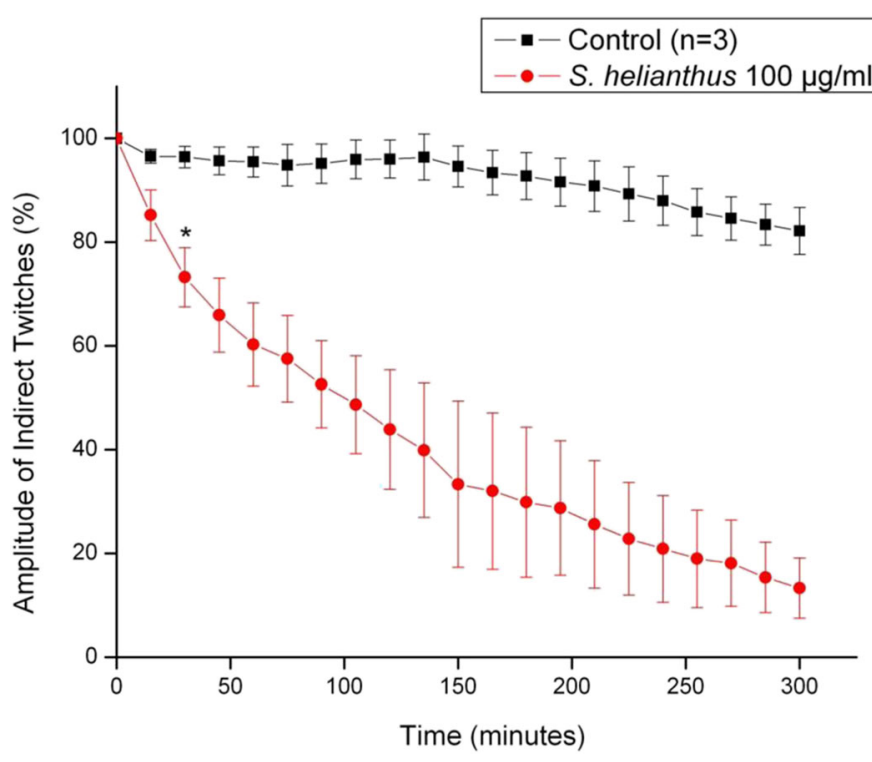

Fig. 7 Effects of S. helianthus extract $(100 \mu \mathrm{g} / \mathrm{mL}$ ) upon indirect evoked twitches on mouse phrenic-diaphragm preparation. The ordinate represents the $\%$ amplitude of twitches relative to the initial amplitude. The abscissa indicates the time (min) after the addition of the extract to the organ bath. Vertical bars represent the SEM; ${ }^{*}$ indicates the point from which there are significant differences relative to control $(p<0.05)$

In isolated neuromuscular preparation, extract from $S$. helianthus $(100 \mu \mathrm{g} / \mathrm{mL})$ induced a time-dependent blockage of indirect twitches (Fig. 7). After 300 min, the twitch amplitude was reduced by about $84 \%$. In contrast, at the same concentration, extracts from C. gigantea (body wall) and C. gigantea (total) did not affect the indirectly evoked twitches. Morphological and morphometric analyses revealed an absence of significant damage in diaphragm muscles exposed to S. helianthus and C. gigantea total extracts (Fig. 8). On the other hand, a slight, but significant level of damage was observed in muscles exposed to $C$. gigantea body wall extract (Fig. 8).

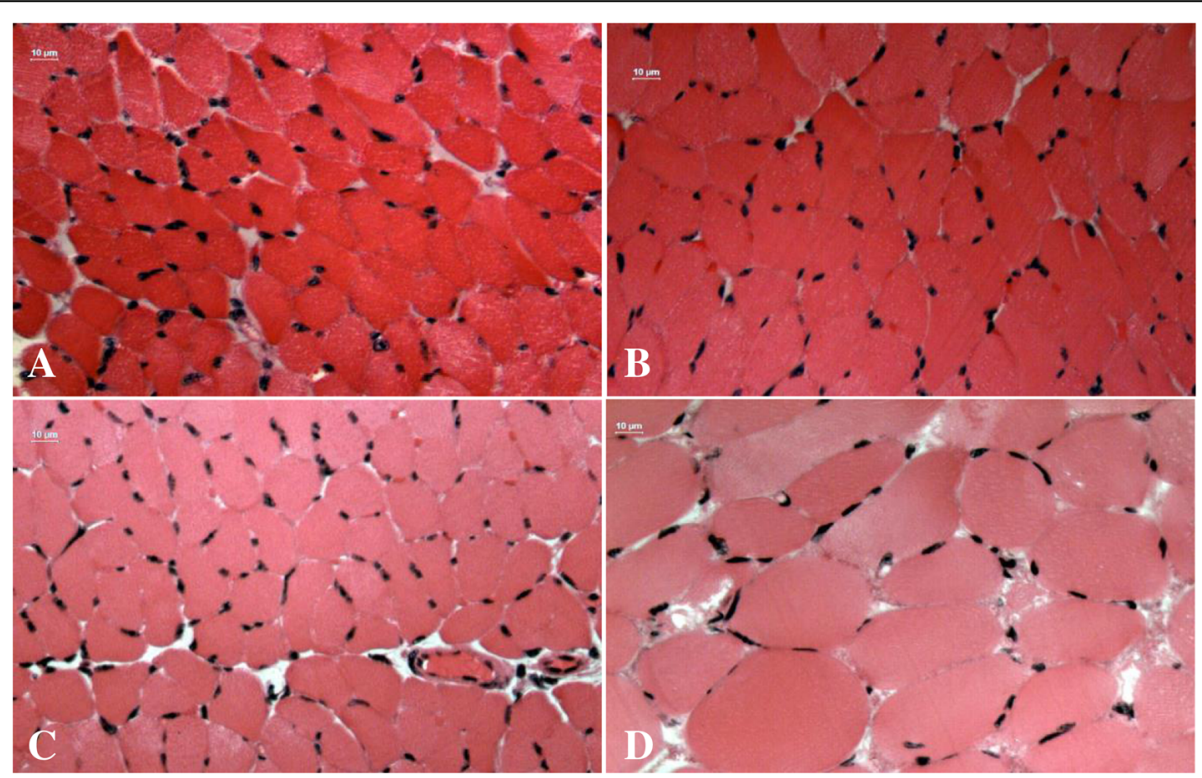

Fig. 8 Light micrographs of mouse diaphragm muscles submitted to hematoxylin and eosin staining. Control muscle (a) and muscles exposed to extracts of C. gigantea (body-wall) (b), C. gigantea (total) (c) and S. helianthus (d). Note the general normal appearance of fibers with polygonal aspect ( $f$ ) and endomysium (en). Muscle damage index of (C) and (D) $(4.3 \pm 1.3, n=5$ and $5.5 \pm 1.1, n=4$, respectively) were not significantly different from that of $(A)(2.0 \pm 0.4, n=5)$. However, muscle damage of $B(5.9 \pm 0.8, n=5)$ was significantly higher than that of $A$. (ANOVA, $p \leq$ 0.05). The remaining cnidarian extracts did not show such activity 
The cytotoxic activity of cnidarian extracts upon the human tumor cell lines JURKAT (leukemia $\mathrm{T}$ ) and B16F10 (melanoma) (Fig. 9a and b) showed that all extracts presented anti-tumor activity against JURKAT cells, except the extract $B$. annulata. Additionally, extracts of C. gigantea (body-wall) and S. helianthus showed significant anti-tumor activity at concentrations of $1000 \mu \mathrm{g} / \mathrm{mL}$, of which the latter still showed cytotoxic activity of $50 \%$ even at the lowest concentration evaluated $(10 \mu \mathrm{g} / \mathrm{mL})$. As to their activity on B16F10 cells, only the extract of C. gigantea (body wall) and M. alcicornis showed anti-tumor activity at concentrations of 1000 and $100 \mu \mathrm{g} / \mathrm{mL}$. Some authors proposed that this cytotoxic activity on tumor cell lines is associated with the induction of apoptosis considering the fact that some enzymes isolated from animals exhibit hydrolytic activity by altering the cell membrane [67]. Another study reported the cytotoxic effect of extracts from the marine sponge Polymastia janeirensis on a human glioma line (U138MG); in the experiment, both aqueous and organic extracts induced cell death by apoptosis and necrosis [68]. Similar results with extracts from the sponge Hyattella cribriformis in ethyl acetate, which exhibited potent

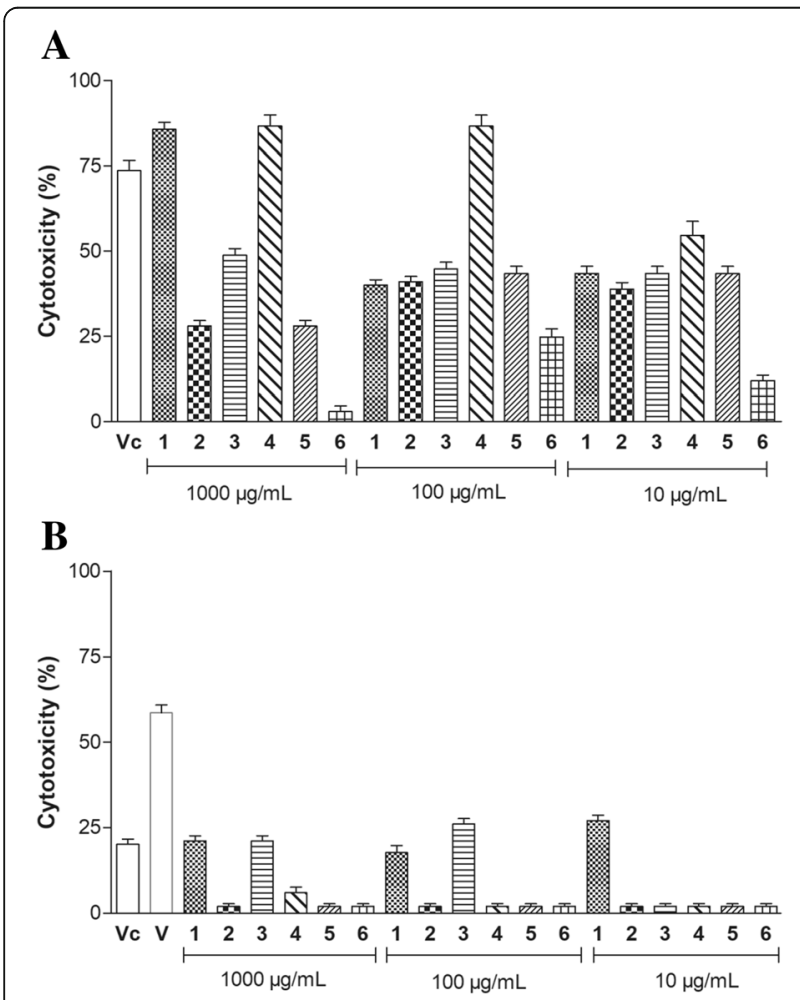

Fig. 9 Anti-tumor activity of cnidarian extracts. (V) Vincristine $100 \mu \mathrm{g} / \mathrm{mL}$, (Vc) Vincristine $10 \mu \mathrm{g} / \mathrm{mL}$, (1) C. gigantea (body-wall), (2) C. gigantea (total), (3) M. alcicornis, (4) S. helianthus, (5) P. homomalla, (6) B. annulata. (a) Antitumoral activity on human acute T-cell leukemia (JURKAT) lines. (b) Antitumoral activity on human melanoma (B16F10). Results are presented as means \pm SD $(n=3)$ growth inhibition of tumor cells as sarcoma, ovarian cancer, colon and breast cell lines [69].

\section{Conclusions}

The neutralization of the clotting induced by $B$. jararacussu snake venom and the inhibition of the hemorrhagic activity induced by $B$. moojeni venom were demonstrated by the majority of the cnidarian extracts tested, whereas the ability to inhibit thrombin-induced coagulation was shown by the C. gigantea (body wall). Together with the anti-tumor effect against JURKAT cells demonstrated by all cnidarian extracts tested and the specificity shown against B16F10 cells, these findings constitute important evidence that cnidarians extracts are a rich source of bioactive molecules that should be studied in order to produce data for the development of new alternatives for snakebite envenomation and cancer therapies.

\section{Acknowledgments}

This work was supported by Ministry of Science and Technology (MCTI), National Council for Scientific and Technological Development (CNPq), Funding Authority for Studies and Projects (FINEP), Coordination for the Improvement of Higher Education Personnel (CAPES), National Research Network in Marine Biotechnology (process no. 408522/2013-5, MCTI/CNPq/ FNDCT) and Rondônia Research Foundation (FAPERO). The authors express their gratitude to Genetic Heritage Management Board (CGEN/MMA) for financial support under the authorization number 010627/2011-1. The authors thank the Program for Technological Development in Tools for Health-PDTIS-FIOCRUZ for use of its facilities. Amy Grabner provided the English editing of the manuscript. The authors thank the Andrea A. Moura, Nestor A. D. Mendes, Anderson M. Kayano, and Auro Nomizo for their collaboration of the work and manuscript.

\section{Funding}

This work was funded by the FIOCRUZ, FAPERO, Conselho Nacional de Desenvolvimento Cientifico e Tecnológico (CNPq), Coordenação de Aperfeiçoamento de Pessoal de Nível Superior, Ministério da Ciência e Tecnologia (MCTI) from Brazil.

\section{Availability of data and materials}

The data sets used and/or analyzed during the current study are available from the authors (CSO, CASC, RDS, DLR, SM), upon reasonable request.

\section{Authors' contributions \\ CSO, CASC, RDS, DLR and SM provided the biochemical and functional characterization. CSO, CASC, RDS, DLR, SM, LAM, ALF, CC, WLGC, MG, MDP and AMS conducted all the experiments, and analyzed and discussed the results obtained. JPZ, LAC, AMS, SM, DLR, MG and ALF participated in the analysis and discussion of the results, carried out a critical review of the work, and assisted in the writing and structuring of the article. AMS, DLR, MG and ALF were responsible for the conception of the work, supervised all the experiments and drafted the manuscript. All the authors read and approved the final manuscript.}

Ethical approval and consent to participate

The procedures with animals are in accordance with the guidelines for the care and uses of laboratory animals from National Research Council, USA. The ethical aspects related to the project were approved by the Ethics Committee for Animal Use (No. 2012/1), (No. 102/2009) and Ethics Committee for Human Research - CEP from Brazil (CAAE: 14204413.5.0000.0011).

Consent for publication

Not applicable.

\section{Competing interests}

The authors declare that they have no competing interests. 


\section{Publisher's Note}

Springer Nature remains neutral with regard to jurisdictional claims in published maps and institutional affiliations.

\begin{abstract}
Author details
${ }^{1}$ Centro de Estudos de Biomoléculas Aplicadas a Saúde (CEBio), Fundação Oswaldo Cruz de Rondônia (Fiocruz Rondônia), Porto Velho, RO, Brazil. ${ }^{2}$ Brazilian Marine Biotechnology Network (BioTecMar Network), Porto Velho, Brazil. ${ }^{3}$ Departamento de Medicina, Universidade Federal de Rondônia (UNIR), Porto Velho, RO, Brazil. ${ }^{4}$ Centro de Estudios de Proteínas, Facultad de Biología, Universidad de La Habana, Havana, Cuba. ${ }^{5}$ Departamento de Química, Universidade Federal de Lavras (UFLA), Lavras, MG, Brazil. ${ }^{6}$ Departamento de Biologia Celular e Molecular (GCM), Instituto de Biologia, Universidade Federal Fluminense (UFF), Niterói, RJ, Brazil. 'Departamento de Farmacologia, Instituto de Biociências, Universidade Estadual Paulista (UNESP), Botucatu, SP, Brazil. ${ }^{8}$ Instituto de Ciências Biológicas, Departamento de Farmacologia, Universidade Federal de Minas Gerais (UFMG), Belo Horizonte, MG, Brazil. ${ }^{9}$ Departamento de Morfologia, Instituto de Biociências, Universidade Estadual Paulista (UNESP), Botucatu, SP, Brazil. ${ }^{10}$ Centro Universitário São Lucas (UniSL), Porto Velho, RO, Brazil.
\end{abstract}

\section{Received: 19 December 2017 Accepted: 7 August 2018}

\section{Published online: 28 August 2018}

\section{References}

1. Frazão B, Vasconcelos V, Antunes A. Sea anemone (cnidaria, anthozoa, actiniaria) toxins: an overview. Mar. Drugs. 2012;10:1812-51.

2. Aneiros A, Garateix A. Bioactive peptides from marine sources: pharmacological properties and isolation procedures. J Chromatogr B Anal Technol Biomed Life Sci. 2004;803:41-53.

3. Cooper EL, Hirabayashi K, Strychar KB, Sammarco PW. Corals and their potential applications to integrative medicine. Evid Based Complement Alternat Med. 2014;2014:184959.

4. Kim S-K, Venkatesan J. Introduction to Marine Biotechnology. Springer Handb. Mar. Biotechnol. 2015:1-10.

5. Choudhary A, Naughton L, Montánchez I, Dobson A, Rai D. Current Status and Future Prospects of Marine Natural Products (MNPs) as Antimicrobials. Mar. Drugs. Multidisciplinary Digital Publishing Institute. 2017;15:272.

6. Mayer A, Rodríguez A, Taglialatela-Scafati O, Fusetani N. Marine Pharmacology in 2012-2013: Marine Compounds with Antibacterial, Antidiabetic, Antifungal, AntiInflammatory, Antiprotozoal, Antituberculosis, and Antiviral Activities; Affecting the Immune and Nervous Systems, and Other Miscellaneous Mechanisms of. Mar. Drugs. Multidisciplinary Digital Publishing Institute. 2017;15:273.

7. Honma T, Shiomi K. Peptide toxins in sea anemones: structural and functional aspects. Mar Biotechnol. 2006;8:1-10.

8. Hernández-Matehuala R, Rojas-Molina A, Vuelvas-Solórzano AA, GarciaArredondo A, Alvarado Cl, Olguín-López N, et al. Cytolytic and systemic toxic effects induced by the aqueous extract of the fire coral Millepora alcicornis collected in the Mexican Caribbean and detection of two types of cytolisins. J. Venom. Anim. Toxins Incl. Trop. Dis. 2015;21:36.

9. Jouiaei M, Casewell NR, Yanagihara AA, Nouwens A, Cribb BW, Whitehead $D$, et al. Firing the sting: chemically induced discharge of cnidae reveals novel proteins and peptides from box jellyfish (Chironex fleckeri) venom. Toxins (Basel). 2015;7:936-50

10. Liew YJM, Soh WT, Jiemy WF, Hwang JS. Mutagenesis and functional analysis of the pore-forming toxin HALT-1 from Hydra magnipapillata. Toxins (Basel). 2015;7:407-22.

11. Takahashi T, Takeda N. Insight into the molecular and functional diversity of cnidarian neuropeptides. Int J Mol Sci. 2015:16:2610-25.

12. Ghazaryan NA, Ghulikyan LA, Kishmiryan AV, Kirakosyan GR, Nazaryan OH, Ghevondyan TH, et al. Anti-tumor effect investigation of obtustatin and crude Macrovipera lebetina obtusa venom in S-180 sarcoma bearing mice. Eur J Pharmacol. 2015;764:340-5.

13. Mukherjee AK, Saviola AJ, Burns PD, Mackessy SP. Apoptosis induction in human breast cancer (MCF-7) cells by a novel venom L-amino acid oxidase (Rusvinoxidase) is independent of its enzymatic activity and is accompanied by caspase-7 activation and reactive oxygen species production. Apoptosis. 2015:20:1358-72.

14. Almeida JR, Resende LM, Watanabe RK, Corassola VC, Huancahuire-Vega S, da S Caldeira CA, et al. Snake venom peptides and low mass proteins: molecular tools and therapeutic agents. Curr Med Chem. 2016;23:1-29.
15. Tong-ngam $\mathrm{P}$, Roytrakul S, Sritanaudomchai H. BmKn-2 scorpion venom peptide for killing oral cancer cells by apoptosis. Asian Pac J Cancer Prev. 2015;16:2807-11.

16. Ketelhut DFJ, Homem De Mello M, ELG V, Esmeraldino LE, Murakami MT, Arni RK, et al. Isolation, characterization and biological activity of acidic phospholipase A2 isoforms from Bothrops jararacussu snake venom. Biochimie. 2003;85:983-91.

17. Estrada-Gómez S, Gomez-Rave L, Vargas-Muñoz LJ, van der Meijden A. Characterizing the biological and biochemical profile of six different scorpion venoms from the Buthidae and Scorpionidae family. Toxicon. 2017;130:104-15.

18. Shahbazzadeh D, Yardehnavi N, Kazemi-Lomedasht F, Bagheri KP, Behdani $\mathrm{M}$. Anticancer activity of $\mathrm{H}$. lepturus venom and its hemolytic fraction (heminecrolysin). HBB. Heal. Biotechnol. Biopharma. 2017;1:46-53.

19. Schmeda-Hirschmann G, Quispe C, Theoduloz C, de Sousa PT, Parizotto C. Antiproliferative activity and new argininyl bufadienolide esters from the "cururú" toad Rhinella (Bufo) schneideri. J Ethnopharmacol. 2014;155:1076-85.

20. Sousa LQ, Machado KD, Oliveira SF, Araújo LD, Monção-Filho ED, MeloCavalcante AA, et al. Bufadienolides from amphibians: a promising source of anticancer prototypes for radical innovation, apoptosis triggering and $\mathrm{Na}$ +/K+-ATPase inhibition. Toxicon. 2017;127:63-76.

21. Abdel-Rahman MA, Abdel-Nabi IM, El-Naggar MS, Abbas OA, Strong PN. Conus vexillum venom induces oxidative stress in Ehrlich's ascites carcinoma cells: an insight into the mechanism of induction. J. Venom. Anim. Toxins Incl. Trop. Dis. 2013;19:10.

22. Lebbe EKM, Tytgat J. In the picture: disulfide-poor conopeptides, a class of pharmacologically interesting compounds. J. Venom. Anim. Toxins Incl. Trop. Dis. BioMed Central; 2016;22:30.

23. Leone A, Lecci RM, Durante M, Piraino S. Extract from the zooxanthellate jellyfish Cotylorhiza tuberculata modulates gap junction intercellular communication in human cell cultures. Mar Drugs. 2013;11:1728-62.

24. Mariottini GL. The role of Cnidaria in drug discovery. Cnidaria, Past: Present Futur. Springer International Publishing; 2016. p. 653-68.

25. Sanderson BJS, Da Silva KB, Ramezanpour M. How venom from the Magnificent Sea Anemone, Heteractis magnifica, kills breast and lung Cancer cells. Cnidaria, Past: Present Futur. Springer International Publishing; 2016. p. 669-81.

26. Gomes A, Bhattacharjee P, Mishra R, Biswas AK, Dasgupta SC, Giri B, et al. Anticancer potential of animal venoms and toxins. Indian J Exp Biol. 2010;48:93-103.

27. Linghong W, Chao D, Xian L, Wenyan H, Xiulan S. Anticancer potential of bioactive peptides from animal sources. Oncol. Rep. [National Hellenic Research Foundation]. 2017:38:637-51.

28. Fan M, Nath A, Tang Y, Choi Y-J, Debnath T, Choi E-J, et al. Investigation of the Anti-Prostate Cancer Properties of Marine-Derived Compounds. Mar. Drugs. Multidisciplinary Digital Publishing Institute. 2018;16:160.

29. Song X, Xiong Y, Qi X, Tang W, Dai J, Gu Q, et al. Molecular Targets of Active Anticancer Compounds Derived from Marine Sources. Mar. Drugs. 2018;16:175. Multidisciplinary Digital Publishing Institute

30. Oliveira JS, Fuentes-Silva D, King GF. Development of a rational nomenclature for naming peptide and protein toxins from sea anemones. Toxicon Elsevier Ltd. 2012;60:539-50.

31. Technau U, Schwaiger M. Recent advances in genomics and transcriptomics of cnidarians. Mar Genomics. 2015;24:131-8.

32. Xie B, Huang Y, Baumann K, Fry B, Shi Q. From Marine Venoms to Drugs: Efficiently Supported by a Combination of Transcriptomics and Proteomics. Mar. Drugs. Multidisciplinary Digital Publishing Institute; 2017;15:103.

33. Avila AD, Mateo de Acosta C, Lage A. A new immunotoxin built by linking a hemolytic toxin to a monoclonal antibody specific for immature $T$ lymphocytes. Int. J. Cancer. 1988:42:568-71.

34. da Silva GA, Domingos TFS, Fonseca RR, Sanchez EF, Teixeira VL, Fuly AL. The red seaweed Plocamium brasiliense shows anti-snake venom toxic effects. J Venom Anim Toxins Incl Trop Dis. 2015;21:2.

35. Domingos TFS, Vallim MA, Cavalcanti DN, Sanchez EF, Teixeira VL, Fuly AL. Effect of Diterpenes isolated of the marine alga Canistrocarpus cervicornis against some toxic effects of the venom of the Bothrops jararaca snake. Molecules. 2015:20:3515-26.

36. da Silva ACR, Pires AMG, Ramos CJB, Sanchez EF, Cavalcanti DN, Teixeira VL, et al. The seaweed Prasiola crispa (Chlorophyta) neutralizes toxic effects of Bothrops jararacussu snake venom. J Appl Phycol Springer Netherlands. 2017;29:781-8.

37. Monti MC, Casapullo A, Cavasotto CN, Napolitano A, Riccio R. Scalaradial, a dialdehyde-containing marine metabolite that causes an unexpected noncovalent PLA 2 inactivation. Chembiochem. 2007:8:1585-91. 
38. Marcussi S, Sant'Ana CD, Oliveira CZ, Rueda AQ, Menaldo DL, Beleboni RO, et al. Snake venom phospholipase $A_{2}$ inhibitors: medicinal chemistry and therapeutic potential. Curr Top Med Chem. 2007;7:743-56.

39. Santos-Filho NA, Silveira LB, Boldrini-França J. Myotoxin Inhibitors. Springer Netherlands; 2017. p. 321-349.

40. Salas-Sarduy E, Cabrera-Muñoz A, Cauerhff A, González-González Y, Trejo SA Chidichimo A, et al. Antiparasitic effect of a fraction enriched in tightbinding protease inhibitors isolated from the Caribbean coral Plexaura homomalla. Exp Parasitol. 2013;135:611-22.

41. Romero Del Sol DL, Luberta A, Dávila L, Barral AM, Garateix A, Mas R, MDLÁ CP. Aislamiento y Purificación parcial de cuatro polipéptidos a partir de la anémona marina Condylactis gigantea. Rev. Biol. 1987;1:3-13.

42. Laemmli UK. Cleavage of structural proteins during the assembly of the head of bacteriophage T4. Nature. 1970;227:680-5.

43. Gutiérrez JM, Chaves F, Rojas E, Elizondo J, Avila C, Cerdas L. Production of monovalent anti Bothrops asper antivenom: development of immune response in horses and neutralizing abilit. Rev Biol Trop. 1988;36:511-7.

44. Harshman S, Sugg N. Effect of calcium ions on staphylococcal alpha toxininduced hemolysis of rabbit erythrocytes. Infect Immun. 1985;47:37-40.

45. Martinez D, Campos AM, Pazos F, Alvarez C, Lanio ME, Casallanovo F, et al. Properties of St I and St II, two isotoxins isolated from Stichodactyla helianthus: A comparison. Toxicon. 2001;39:1547-60.

46. Rodrigues VM, Soares AM, Guerra-Sá R, Rodrigues V, Fontes MR, Giglio JR. Structural and functional characterization of neuwiedase, a nonhemorrhagic fibrinogenolytic metalloprotease from Bothrops neuwiedi snake venom. Arch. Biochem. Biophys. 2000;381:213-24.

47. Van Der Walt SJ, Joubert FJ. Studies on puff adder (Bitis arietans) venom I. Purification and properties of protease a. Toxicon. 1971;9:153-61.

48. Kondo $\mathrm{H}$, Kondo S, Ikezawa H, Murate R, Ohsaka A. Studies on the quantitative method for determination of hemorrhagic activity of Habu snake venom. Jap J M Sc Biol. 1960;13:43-51.

49. Cavalcante WLG, Campos TO, Dal Pai-Silva M, Pereira PS, Oliveira CZ, Soares AM, et al. Neutralization of snake venom phospholipase $A_{2}$ toxins by aqueous extract of Casearia sylvestris (Flacourtiaceae) in mouse neuromuscular preparation. J Ethnopharmacol. 2007;112:490-7.

50. McManus JFA, Mowry RW. Staining Methods. Histologic and histochemical. Science.80). 1960;133:1009-1009.

51. Soares AM, Guerra-Sá R, Borja-Oliveira CR, Rodrigues VM, Rodrigues-Simion $L$, Rodrigues VM, et al. Structural and functional characterization of BnSP-7, a Lys49 myotoxic phospholipase $A_{2}$ homologue from Bothrops neuwiedi pauloensis venom. Arch Biochem Biophys. 2000;378:201-9.

52. Soares AM, Mancin AC, Cecchini AL, Arantes EC, França SC, Gutiérrez JM, et al, Effects of chemical modifications of crotoxin $B$, the phospholipase $A_{2}$ subunit of crotoxin from Crotalus durissus terrificus snake venom, on its enzymatic and pharmacological activities. Int J Biochem Cell Biol. 2001;33:877-88.

53. Mosmann T. Rapid colorimetric assay for cellular growth and survival: application to proliferation and cytotoxicity assays. J Immunol Methods. 1983;65:55-63.

54. Martins RD, Alves RS, Martins AMC, Barbosa PSF, Evangelista JSAM, JJF E, et al. Purification and characterization of the biological effects of phospholipase A2 from sea anemone Bunodosoma caissarum. Toxicon. 2009;54:413-20.

55. Lanio ME, Morera V, Alvarez C, Tejuca M, Gómez T, Pazos F, et al. Purification and characterization of two hemolysins from Stichodactyla helianthus. Toxicon. 2001;39:187-94.

56. del Monte-Martínez A, González-Bacerio J, Romero L, Aragón C, Martínez D, de los Á Chávez M, et al. Improved purification and enzymatic properties of a mixture of Sticholysin I and II: isotoxins with hemolytic and phospholipase $\mathrm{A}_{2}$ activities from the sea anemone Stichodactyla helianthus. Protein Expr Purif. 2014;95:57-66

57. Santamaría A, Sánchez-Rodríguez J, Zugasti A, Martínez A, Galván-Arzate S, Segura-Puertas L. A venom extract from the sea anemone Bartholomea annulata produces haemolysis and lipid peroxidation in mouse erythrocytes. Toxicology. 2002;173:221-8.

58. Monroy-Estrada HI, Segura-Puertas L, Galván-Arzate S, Santamaría A, Sánchez-Rodríguez J. The crude venom from the sea anemone Stichodactyla helianthus induces haemolysis and slight peroxidative damage in rat and human erythrocytes. Toxicol Vitr. 2007;21:398-402.

59. Cilli EM, Pigossi FT, Crusca E, Ros U, Martinez D, Lanio ME, et al. Correlations between differences in amino-terminal sequences and different hemolytic activity of sticholysins. Toxicon. 2007;50:1201-4.
60. Celedón G, González G, Barrientos D, Pino J, Venegas F, Lissi EA, et al. Stycholysin II, a cytolysin from the sea anemone Stichodactyla helianthus promotes higher hemolysis in aged red blood cells. Toxicon. 2008;51:1383-90.

61. Alvarez C, Pazos IF, Lanio ME, Martinez D, Schreier S, Casallanovo F, et al. Effect of pH on the conformation, interaction with membranes and hemolytic activity of sticholysin II, a pore forming cytolysin from the sea anemone Stichodactyla helianthus. Toxicon. 2001;39:539-53.

62. Huerta V, Morera V, Guanche Y, Chinea G, González LJ, Betancourt L, et al. Primary structure of two cytolysin isoforms from Stichodactyla helianthus differing in their hemolytic activity. Toxicon. 2001;39:1253-6.

63. Lanio ME, Alvarez C, Ochoa C, Ros U, Pazos F, Martínez D, et al. Sticholysins I and II interaction with cationic micelles promotes toxins' conformational changes and enhanced hemolytic activity. Toxicon. 2007;50:731-9.

64. Pascual I, Lopéz A, Gómez H, Chappé M, Saroyán A, González Y, et al. Screening of inhibitors of porcine dipeptidyl peptidase IV activity in aqueous extracts from marine organisms. Enzym Microb Technol. 2007;40:414-9.

65. Di Bari G, Gentile E, Latronico T, Corriero G, Fasano A, Nonnis Marzano C, et al. Inhibitory effect of aqueous extracts from marine sponges on the activity and expression of Gelatinases a (MMP-2) and B (MMP-9) in rat astrocyte cultures. PLoS One. 2015;10

66. García-Arredondo A, Rojas-Molina A, Bah M, Ibarra-Alvarado C, GallegosCorona MA, García-Servín M. Systemic toxic effects induced by the aqueous extract of the fire coral Millepora complanata and partial purification of thermostable neurotoxins with lethal effects in mice. Comp Biochem Physiol C Toxicol Pharmacol. 2015;169:55-64.

67. Samy RP, Gopalakrishnakone P, Chow VT. Therapeutic application of natural inhibitors against snake venom phospholipase A2. Bioinformation. 2012;8:48-57.

68. da Frota MLC, Braganhol E, Canedo AD, Klamt F, Apel MA, Mothes B, et al. Brazilian marine sponge Polymastia janeirensis induces apoptotic cell death in human U138MG glioma cell line, but not in a normal cell culture. Investig New Drugs. 2009;27:13-20.

69. Annamalai P, Thayman M, Rajan S, Raman LS, Ramasubbu S, Perumal P. Ethyl acetate extract from marine sponge Hyattella cribriformis exhibit potent anticancer activity by promoting tubulin polymerization as evidenced mitotic arrest and induction of apoptosis. Pharmacogn Mag. 2015;11:345-55.

\section{Ready to submit your research? Choose BMC and benefit from:}

- fast, convenient online submission

- thorough peer review by experienced researchers in your field

- rapid publication on acceptance

- support for research data, including large and complex data types

- gold Open Access which fosters wider collaboration and increased citations

- maximum visibility for your research: over $100 \mathrm{M}$ website views per year

At $\mathrm{BMC}$, research is always in progress.

Learn more biomedcentral.com/submissions 